\title{
Indonesia, ASEAN Centrality and Global Maritime Fulcrum
}

\author{
Putri Auliya \& Yohanes Sulaiman \\ Universitas Jendral Achmad Yani
}

\begin{abstract}
Why Indonesia remains committed to maintain centrality of ASEAN in its Indo-Pacific strategy as a way to deter conflicts, especially in light of President Joko "Jokowi” Widodo's famous proclamation of "Global Maritime Fulcrum?" The main thrust of "Global Maritime Fulcrum" doctrine is that in order to face shifting geopolitical and economic power from the West to Asia, Indonesia needs to face the challenge by putting Indonesia's interest back to the forefront of global political and economic discourse. Yet, by the end of the day, Indonesia remains committed in pushing for the centrality of ASEAN especially in dealing with potential conflicts in the Indo-Pacific region. By stressing the centrality of ASEAN, meaning that Indonesia is attempting to strengthen cooperation between the members of ASEAN and crafting a cooperative regional framework, Indonesia and ASEAN as a whole may be able to reduce the tension due to the clashing interest of the United States and China in Indo-Pacific region.
\end{abstract}

Keywords: Indonesia, Global Maritime Fulcrum, ASEAN centrality, geopolitical and economic power

Mengapa Indonesia tetap menekankan sentralitas ASEAN dalam strategi Indo-Pasifiknya sebagai cara untuk menghindari konflik, terutama setelah proklamasi Presiden Joko Widodo mengenai Poros Maritim Dunia? Argumen utama doktrin Poros Maritim Dunia adalah menghadapi perubahan kekuasaan geopolitics dan ekonomi dari Barat ke Asia, Indonesia perlu menghadapi tantangan dengan mengembalikan kepentingan Indonesia ke hadapan diskursus politik dan ekonomi global. Namun pada akhirnya, Indonesia tetap memiliki komitmen untuk mendorong sentralitas ASEAN dalam menghadapi potensi konflik di kawasan Indo-Pasifik karena sentralitas ASEAN tetap penting dalam menignkatkan kerjasama antara negara-negara ASEAN dan membentuk kerangka kerjasama regional, dan Indonesia dan ASEAN secara keseluruhan dapat mengurangi ketengangan yang disebabkan pertentangan kepentingan Amerika Serikat dan China di kawasan Indo-Pacific.

Kata-kata kunci: Indonesia, Global Maritime Fulcrum, sentralitas ASEAN, kekuatan geopolitik dan ekonomi 
Why Indonesia remains committed to maintain centrality of ASEAN in its Indo-Pacific strategy as a way to deter conflicts, especially in light of President Joko "Jokowi" Widodo's famous proclamation of "Global Maritime Fulcrum?" The main thrust of "Global Maritime Fulcrum" doctrine is that facing shifting geopolitical and economic power from the West to Asia, Indonesia needed to face the challenge by putting Indonesia's interest back to the forefront of global political and economic discourse (Witular 2014). In a sense, under the "Global Maritime Fulcrum," Indonesia is supposedly focusing more on itself than the rest of ASEAN. Of course, this does not mean that Indonesia is going to completely abandons ASEAN, but the onus of Indonesian policy should be mostly on Indonesia itself. As Jokowi himself bluntly stated that Indonesia's diplomatic approach must not be "the sort of diplomacy that spend money, but one that makes money (Sheany 2018)." As a result, many observers saw Jokowi as focusing more on bilateral than multilateral relations, and Indonesia was becoming less and less oriented toward the ASEAN (Poole 2015).

Yet, by the end of the day, Indonesia remains committed in pushing for the centrality of ASEAN especially in dealing with potential conflicts in the Indo-Pacific region. As Foreign Minister Retno Marsudi stated in her annual press statement, strengthening the unity and centrality of ASEAN as a key player in the region remains one of the main focus of Indonesian foreign policy (Leo 2018). The reason is that at this point, due to its relative weakness, Indonesia really does not have much choice except to focus on the centrality of ASEAN itself, as a way to increase its diplomatic clout. Should Indonesia be successful, it will help binding at least ten nations into the position of benign neutrality that hopefully could help reducing the tension in the region. At the same time, by pushing the centrality of ASEAN, this will help amplifying Indonesia's voice, that Indonesia can punch above its weight due to its regional leadership.

The changes in political constellation in Indo-Pacific region due to growing influence and tension between the United States and China lead to growing regional instability. As a result, the possibility of conflict and military clashes occurring is getting higher and higher. And this conflict will inadvertently drag many states into it, as both the United States and China have been increasing its clout, through regional architecture that they created, in the United States' case, its military alliances, and in China's case, its "Belt and Road" project and some of the states that are going to be involved in the dispute between the United States and China is located in Southeast Asia, in Indonesia's backyard. And this is the main reason why ASEAN, with Indonesia taking the lead, needs to pick a stance to be able to defend and enhance its role in the Souteast Asia region, and gradually, also broaden its role in the Indo-Pacific region. In order to do that, first ASEAN needs to focus on crafting a coherent united policy to deal with problems in Indo-Pacific region (Laksmana 2018b).

Moreover, ASEAN has a significant role in the Indo-Pacific concept, as it is strategically located right in the middle of Indo-Pacific, between Indian and Pacific oceans, and thus becomes a lynchpin of this regional concept (Chen 2018). This in turn, gives ASEAN the role to contribute by maintaining the stability of the region, achieving security, peace, and regional stability through utilizing its cooperative framework and strong commitment among its members and its partners outside ASEAN (Kementerian Luar Negeri Republik Indonesia 2012). By stressing the centrality of ASEAN, meaning that Indonesia is attempting to strengthen cooperation between the members of ASEAN and crafting a cooperative regional framework, Indonesia and ASEAN as a whole may be able to reduce the tension due to the clashing interest of the United States and Chi- 
na in Indo-Pacific. The mechanism of ASEAN-led cooperative framework will become the media, the meeting points that moderate, combine, and communicate the interests between various powers in the region, in a more objective framework, meaning states, regardless of their power and capability, may have the opportunity to accomplish mutually beneficial relationship between everyone in the region (Kementerian Luar Negeri Republik Indonesia 2019).In turn, Indonesia's foreign policy that stresses the centrality of ASEAN is relevant to the Strategic Planning of Foreign Ministry of Indonesia 2015-2019 that stresses the need to increase the role and leadership of Indonesia in ASEAN.

\section{Theoretical Argument: ASEAN and Indonesia}

As growing need in human lives will keep increasing the complexity in the international relations, including due to globalization, which increase the connectivity among states, the possibility for conflicts in various different area of interaction will keep growing. That, however, also includes spaces where states can cooperate to craft mutually beneficial relationship. Therefore, states, specifically political and professional elite, should always try to engage in mutually beneficial cooperation, as it is always be the best answer to reduce the potential for conflicts (Haas 1964). While liberal institutionalists agree that it is difficult to develop cooperation among states, at the same time, the potential for profit by cooperation makes it worthwhile for states to take a risk, and to build common trust (Keohane 1984). As each state has different background and need in fulfilling its needs in order to maintain itself, this creates the foundation for cooperation, that each state can go alone and risk scarcity, or they can cooperate together to gain benefits that they cannot get on their own. This becomes the foundation for mutually cooperative relationship, that they by the end of the day, will be more dependent to other states to fulfill their needs. And this will affect how states behave in order to maintain their relationship. And the stronger the cooperative relationship, the higher the interdependence, and more importantly, the higher the level of trust is as they all more and more believe that each state will be commited to this cooperative relationship and will try to do their best to maintain this relationship for their own (and common) profit. And through the involvement in complex profitable cooperative relationship, states then would develop an interconnected network of interpendence (Kodoldko 2011) which will increase the mutually beneficial relationship that would reduce the potential for conflicts (Keohane \& Nye 1977).

In essence, states will always end up maintain long-term mutually beneficial relationship and would be less interested in destroying it, since building trust take a lot of time and energy, with the risk of states that would try to take advantage of them for short-term personal gains (Whyte 2012). This also applies to cooperation within institutions, such as ASEAN. Regardless how hard it is to commit in ASEAN and to build a working relationship due to different backgrounds and interests of member states, by the end of the day, members of ASEAN will try to maintain this relationship because they see ASEAN as giving them the opportunity to cooperate and thus serving their interest. Then, the accepted ASEAN's mechanism and regulations serves as framework for cooperation in order to increase trust and relationship in that institution.

Thus, the relevancy of the presence of an institution: it is needed to regulate cooperative relationship through clear and structurized regulations and mechanisms, allowing 
states to reduce risks and to keep building up trust, and allowing for further space for more cooperation - and profit. Each state belongs to the institution, such as Indonesia, will benefits and think further of how the institution could keep giving them benefits and moderating each other's competing interests, allowing everyone to benefit and to reduce competitions and the possibility of domination from one aggressive state, as everyone thinks that they are all equal and unwilling to kill this goose that lays golden eggs. In other words, institutions will moderate states belonging to it in order to gain mutually beneficial trust through coordinating actions of its member states (Keohane and Martin 1995).

It is the main reason why Indonesia should always try to actively push for the centrality of ASEAN, meaning that each state should try to coordinate through unity, as united members of ASEAN, so ASEAN could fufill its goal as an institution, a regional organization that maintain the stability of the region and ready to face challenges and threats in the region. Indonesia sees the Indo-Pacific region that is currently the battleground for competition between two big states that could cause conflicts and Indonesia's focus on the centrality of ASEAN as the moderating factor could be a way to reduce the potential for conflict, and push Indonesia's further into taking the strategic role as a regional initiator and mover. Indonesia could, in essence, could create the habits of consultation, where leaders could meet, discuss, and agree, instead of engaging in conflicts (Natalegawa 2011). More importantly, though, Indonesia could compensate its weakness in power-projecting capability by using ASEAN, as ASEAN, through its grouping, could magnify its members' power, enabling them to influence the region beyond their own capabilities (Anwar 1994). The involvement of ASEAN allows Indonesia to bring everyone together, including the United States and China, as dialogue partners within the common cooperative of ASEAN-led mechanism in order to reduce the possibility of conflicts through intensive communication and common understanding in order to benefit everyone. This kind of solution that can answer the problem of how big powers, such as the United States and China, could agree to make ASEAN as a central moderator in the region, and to make them acknowledge that ASEAN has enough power and capability to make them relevant and to be taken seriously by both the United States and China in pursuing their own interests.

\section{Indonesia and ASEAN Centrality}

Indonesia maintains the centrality of ASEAN as the key to maintain the stability in the region, and this becomes more and more important with growing tension in the region, that has impact on regional politics and economics (Wadrianto, 2016). As noted by Singaporean Minister of Defense Ng Eng Hen, both the United States and China were "changing the rules of the international order" and the problem was that both these countries also did not agree on "one rule-based order (Champion 2018)." This increase in competition not only leads to the increase in the potential of conflicts, but also both countries have been expanding its power and influence in the region. The United States has been pursuing a strategy to contain China, preventing it from becoming a regional threat, by setting up the Quad, a cooperative forum with India, Japan, and Australia (Tsvetov 2017). At the same time, China has been setting up its Belt and Road Innitiative program in order to increase support and partners from the possibilities of 103 states impacted by this program, which promises to open strategic accesses and to help economic developments, and to increase connectivity and eco- 
nomic relationship among states (Minghao 2018).

Southeast Asia is basically caught in the middle, as a region for the competition and to expand their market and influence, with the risk of the region will be dominated by either the United States or China, or even both, and this will destroy the unity of ASEAN. Moreover, China has been especially aggressive due to its inceasing economic might. Since 2006, China has been the global economic mover, replacing the role of the United States and the European Union (Van Sant 2016). This position causes ASEAN states to develop strong economic relationship with China due to its perceived economic benefits. At the same time, ASEAN also feared China's domination in the region, especially due to the potential of the BRI projects ending up to be a "debt-trap", since the projects focus more on benefiting China than the host state, and thus the host state may be saddled with so much debt that it could never repay due to both overambition and the lack of transparency (Laksmana 2018b). Thus, ASEAN needs to pick a neutral position in order to both maintaining the good relationship with the United States and China and at the same time, preventing either countries from dominating the region, considering the fact that both the United States and China are pursuing the expansive strategy of increasing their dominance and influence in the region, splitting the region into competing blocs. ASEAN has the duty to maintain the unity of its member states and regional stabity as a whole.

\section{Global Maritime Fulcrum and Indonesia's Maritime Diplomacy}

As one of the founders of ASEAN, Indonesia's foreign policy goal is to increase the role and leadership of Indonesia in regional cooperation, especially within the ASEAN framework (Kementerian Luar Negeri Indonesia, 2015). In order to do that, in the beginning of Joko "Jokowi" Widodo administration, his goal is to increase Indonesia's role by utilizing Indonesia's own strategic geographic potential. This policy, called Global Maritime Fulcrum, stressed that Indonesia needs to utilize its maritime potentials in initiating and increasing maritime cooperation through maritime diplomacy (Montratama, et al. 2016). This means that the focus of Indonesia's foreign policy under Jokowi Administration is in utilizing its advantage as a maritime state, with a lot of maritime potential to utilize, making Indonesia as the most important state in the region. One of the focus of Indonesia's maritime diplomacy is through Indian Ocean Rim Association (IORA) to support Global Maritime Fulcrum. By opening the possibility of cooperation in maritime aspect in the Indian Ocean through IORA, Indonesia is basically trying to expand the opportunity to achieve the concept of Global Maritime Fulcrum, at least from looking at the potential in the region, and by utilizing its own position as a member of IORA (Sihombing 2017).

Here Indonesia shows its interest to become an important sole player, with enough strength and to have a leading role in the region. The purpose of this concept of Global Maritime Fulcrum, in essence, is to strengthen Indonesia's own role as the main leader in the region, and to some degree, sidelining the centrality of ASEAN itself. Indonesia, however, conveyed its concept of Global Maritime Fulcrum in the Ninth East Asia Summit in Nay Pyi Taw, Myanmar (Kementerian Luar Negeri Indonesia 2014). By promoting its concept of Global Maritime Fulcrum through an ASEAN forum, Indonesia basically signaled its intention that even though it had the interest to lead the region with its maritime advantages, Indonesia still needed ASEAN as its current po- 
litical strength was not enough to lead the region.

More importantly, as noted by Minister of Fisheries Susi Pudjiastuti, this concept also still needed a lot of tinkering, as Indonesia still did not have the masterplan that would determine how and the direction of the implementation of this concept, and how Indonesia could coordinate its implementation, especially among the Indonesian bureaucracy (Kuwado 2017). It has to be admitted that Indonesia's main weakness in the concept of Global Maritime Fulcrum is in the strategy, or foreign policy goals, especially in the aspects of technology, maritime industry, and human resources (Kelen 2014). And this is why this concept needs to be clarified and strengthened since this concept is concerning Indonesia's interest in the region. Moreover, with the grouping of the entire Indian Ocean and Pacific Ocean as one single strategic theatre, this also allows Indonesia to use the arena to expand this concept further, leading Indonesia to be able to utilize its concept to expand relationship and cooperation with other states, in various area, to increase its regional role and to achieve its national interest.

\section{ASEAN Centrality: A Strategy}

Without any clear direction of the concept as a guide for its implementation, however, Indonesia will still have to rely on ASEAN as a media to convey its goals and interests, as an initiative to international audience, especially to other countries in Asia-Pacific. Also, Indonesia believes that in putting the centrality of ASEAN, Indonesia is setting up ASEAN to become a forum for cooperation and to maintain the good constructive relationship among states in the region, and in turn, this will help Indonesia to strengthen its strategic role in its relationship with much bigger powers (Laksmana 2010). In essence, Indonesia believes it has the ability to maintain regional stability through strong communication with fellow ASEAN members and synergic cooperation, allowing ASEAN to be a respected and trusted potential partner and also an independent power by other states, such as the United States, China, Japan, Australia, India, and various other states. And the ASEAN-led mechanism, in turn, will become the important, special trigger that will influence the regional and international political constellation (Caballero-Anthony 2014).

Besides, ASEAN is in position to make impacts. It has a track record of maintaining regional stability through maximizing cooperation and trust-building since its inception in 1967. It already has a regional framework, and networks with various states ouside ASEAN. Moreover, it also has a strong potential for economic growth, with growing educated and young workforce, emerging middle class, and GDP growth averaging $5.4 \%$ in recent years. It is set to be the fourth largest economy in the world by 2030 (Lee 2018).

Moreover, ASEAN could benefit from the United States-China economic disputes that would allow ASEAN to become an alternative economic partner for both countries (Sinintya 2018), which is also an important bargaining chip that could be used against both the United States and China. As noted by Indonesian Foreign Minister Retno Marsudi, ASEAN's centrality meant ASEAN could synergize interests and roles of states that belonged to it to advance in the region. In turn, members of ASEAN, notably Indonesia, must see the opportunities from the strategic role and position of ASEAN in the Indo-Pacific region, by strengthening mutual cooperation and understanding, 
leading to peace and prosperity not only within ASEAN itself, but also in the Indo-Pacific region (Marsudi 2018). This is in line with former Indonesian Foreign Minister Marty Natalegawa who stressed the importance of Indo-Pacific regional connectivity as the lynchpin for global economic development, regional stability, and common prosperity. At the same time, Natalegawa also warned the lack of trust in the region, lack of commitment to difuse and solve disputes, and the need for ASEAN states to welcome and nudge China into obeying regional norms in order to make it a part of international society, which is also known as dynamic equilibrium (Natalegawa 2013).

In essence, Indonesia has long found it important and focused its attention to the political dynamics in the region Indo-Pacific region, especially with so many problems and potential for conflicts due to the lack of trust in the region, which will inadvertently lead to the worsening of regional stability and cooperation in the region. This, in turn, will become a potential threat for the region due to the lack of commitment and communication to create a common perspective that would foster the feeling of duty and responsibility to maintain peace. Therefore, Indonesia will have to decide what the best policy it should take, advocate, and defend, and what policy it is not ready yet to pursue due to lack of power. And that, in turn what makes working together within ASEAN framework appealing: that Indonesia can broaden its role within and outside ASEAN, utilizing ASEAN-led mechanism.

With this goal, Indonesia realizes that in the Indo-Pacific region, the potential for conflict remains present due to the competing interests from the great powers, The United States, China, Japan, and India, that stress their own interests without looking at the global political and legal arrangements. By stressing Indo-Pacific region as the focus of its foreign policy, Indonesia will have enough achievements to increase its role and to fulfill the goal of the Global Maritime Fulcrum and making its proactive activities in the Indo-Pacific region to have significant impacts. Plus, in opening and expanding and strengthening the relationship between Indonesia and other states in the Indo-Pacific region in order to support Indonesia's present and future roles and interests, both Indonesia and ASEAN need to strengthen and maintain structurized and integrated cooperative mechanism that involve states in the region in a complex association to achieve common prosperity. It can also become a forum to communicate the differences in perspective, goals, and interests, and to strengthen profitable bilateral and multilateral relationships. This, in turn, can strengthen interdependence as a foundation for trust and commitment for states in the region to unite for common prosperity.

By stressing the centrality of ASEAN and the need for mutually profitable independent cooperation, ASEAN could maintain the stability in the region in partnership with its members or states outside the association through stressing the principle of active and free foreign policy (Kementerian Luar Negeri Republik Indonesia 2017). Moreover, Indonesia and ASEAN could avoid the domination from the struggle for power between the competing great powers by stressing the principle of non-bloc (Sebastian 2014), giving ASEAN a significant role to prove the neutrality of non-aligned ASEAN by accomodating everyone's interests through ASEAN-led mechanism. This cooperative mechanism is constructed and expanded from ASEAN as its core, the to expand further regionally and internationally, and becoming the main forum for international cooperation and communication (Kementerian Luar Negeri Indonesia 2015). 
ASEAN Led-Mechanism as Support System for Peace ASEAN led-mechanisms, such as East Asia Summit (EAS), ASEAN Defense Ministers Meeting Plus (ADMM+), ASEAN Maritime Forum (AMF), and other cooperative structure could unite and modernize the interests of all partners of cooperation, who are interested to benefit from strong cooperative economics or the connectivity in Indo-Pacific region, by providing the equal opportunity to maintain common prosperity. Through cooperative cooperation that has the principle of openness and inclusivity, that originally used on various internal ASEAN cooperation, ASEAN will gain the opportunity to involve many more cooperative partners in order to craft a complex interdependencies. Indonesia in facing the United States and China chose to adhere to the policy of pragmatic equidistance, meaning that without offending any party or even cutting the relations between any party, Indonesia could involve those great powers in the complex cooperative mechanisms (Laksmana 2018a). And that explains why Indonesia chose ASEAN as the media for creating and utilizing the complex interdependence.

Take the example of the involvement of both the United States and China in the $33^{\text {rd }}$ ASEAN summit in Singapore, when both states managed to gain influence among members of ASEAN by convincing these states of their visions and roles in the IndoPacific region. Both states have calculated the importance of support of Southeast Asian states to their interest in Indo-Pacific region. The United States stressed its commitment to respect the sovereignty of states and international law. China, on the other hand, stressed its economic might and economic connectivity through its Belt and Road project. They also used the summit to attack each other, The United States by stressing its support for freedom of navigation in South China Sea, while China stressed its commitment for peace (Ariffin 2018).

Both states competed using the ASEAN forum that was set up by the ASEAN states, meaning that they consider ASEAN as an important enough player to warrant their presence. While the competition of both states may lead to conflict, at the same time, by being in the ASEAN Summit, and thus finding ASEAN to be important, ASEAN states has a leverage to become a peacemaker ASEAN basically can present itself as a moderator and a forum for international communication and conflict resolution, thus reducing misperception and miscommunication. As a neutral mediator, ASEAN could both show its strength as a key player in the Indo-Pacific region, and at the same time, provide excellent opportunities for economic cooperation. And that is the reason why President Jokowi in the end stresses the importance of ASEAN as a key player in IndoPaciic region, in turning conflict into cooperation (Aditya 2018). This shows Indonesia's commitment in putting the ASEAN Centrality as its foreign policy priority in managing regional political order that is marked with tension and instability, to become more orderly, by opening the communication channel and discussion for common peace.

\section{Conclusion}

Indonesia's foreign policy goals are in stressing the centrality of ASEAN in dealing with various problems in Southeast Asia and Indo-Paciic region, and to increase Indonesia's strategic role in ASEAN and in Indo-Pacific region. Even though Indonesia tried to strengthen its own role through promoting the concept of Global Maritime Fulcrum, in the end, the weaknesses in Indonesia's political power forced Indonesia to rely on ASEAN. Still, Indonesia's initiative to keep strengthening the centrality of ASEAN is 
important steps to open and to strengthen Indonesia's own role in maximizing and expanding its potential power. Due to its role and strategic potential in Indo-Pacific region, ASEAN has managed to become the forum for both the United States and China to iron out their differences and to communicate their interests, binding them into complex interdependencies. The establishment of communicative channel and common interest in achieving regional peace and prosperity becomes the foundation for regional interdependency among involved actors, and this will in turn, reduce the tension in the region. Thus, by the end of the day, Indonesia's goal in strengthening the centrality of ASEAN provides Indonesia not only with the opportunity to increase its role in ASEAN, but also in the Indo-Pacific region as a foundation to strengthen its influence in order to achieve its foreign policy goals.

\section{References}

\section{Book and Chapters in Book}

Anwar, Dewi Fortuna. 1994. Indonesia in ASEAN: Foreign Policy and Regionalism. Singapore: Institute of Southeast Asian Studies.

Haas, Ernst B. 1964. Beyond the Nation State. Stanford: Stanford University Press.

Kementerian Luar Negeri Republik Indonesia, 2012. ASEAN Selayang Pandang Jakarta: Kementerian Luar Negeri Republik Indonesia.

Kementerian Luar Negeri Republik Indonesia, 2015. Rencana Strategis Kementerian Luar Negeri 2015-2019 [Strategic Planning for the Ministry of Foreign Affairs 2015-2019. Jakarta: Kementerian Luar Negeri Republik Indonesia.

Keohane, Robert O. 1984. After Hegemony: Cooperation and Discord in The World Political Economy. Princeton, NJ: Princeton University Press.

Keohane, Robert O. and Joseph Nye, 1977. Power and Interdependence. Boston: Little, Brown.

Kolodko, Grzegorz W. 2011. Truth, Errors, and Lies: Politics and Economics in a Volatile World. Princeton, N.J.: Princeton University Press

Montratama, Ian, Yohanes Sulaiman and Untung Surapati, 2016, Arung Samudera Bersama Sang Naga. Jakarta: Elex Media Komputindo.

\section{Journal and Online Journal}

Caballero-Anthony, M., 2014. "Understanding ASEAN's centrality: bases and prospects in an evolving regional architecture", The Pacific Review, 27(4): 563-584.

Keohane, Robert O. and Lisa L. Martin, 1995. "The Promise of Institutional Theory”. International Security, 20 (1): 39-51.

Natalegawa, Marty. 2011. "Aggressively waging peace: ASEAN and the Asia-Pacific." Strategic Review: The Indonesian Journal of Leadership, Policy and World Affairs, 1 (2): $40-46$ 


\section{Online Articles}

Aditya Ars. 2018. "Jokowi Angkat Konsep Indo-Pasifik di Sidang Pleno KTT ASEAN [Jokowi raises the Indo-Pacific concept in pleminiary session of ASEAN Summit", CNBCIndonesia, 14 November [online] https://www.cnbcindonesia. com/news/20181114075754-4-42023/jokowi-angkat-konsep-indo-pasifik-di-sidang-pleno-ktt-asean [acessed at 13 January 2019]

Ariffin, Eijas. 2018. " $33^{\text {rd }}$ ASEAN Summit: Analysis and key takeaways", The ASEAN Post, 16 November [online] https://theaseanpost.com/article/33rd-asean-summit-analysis-and-key-takeaways. [accessed at 13 January 2019]

Bachdar, Saviq. "ASEAN Butuh China atau China Butuh ASEAN? [ASEAN needs China or China needs ASEAN]" [online] http://marketeers.com/asean-butuh-china-atau-china-butuh-asean/ [accessed 5 January 2019]

Champion, Marc. 2018. "Asia Sees China, and U.S., as Threats to Rules-Based Order," Bloomberg, June 3. [online] https://www.bloomberg.com/news/articles/2018-06-03/asia-sees-china-as-threat-to-rules-based-order-and-the-u-s-too. [accessed at 13 January 2019]

Chen, Dingding. 2018. "Indo Pacific Strategy: Background Analysis", Istituto Per Gli Studi di Politica Internazionale, 4 June. [online] https://www.ispionline.it/it/pubblicazione/indo-pacific-strategy-background-analysis-20714 [accessed at 5 January 2019]

Kementerian Luar Negeri Republik Indonesia, 2014. "Presiden Jokowi Deklarasikan Indonesia Sebagai Poros Maritim Dunia [President Jokowi Declared Indonesia as Global Maritime Fulcrum]", Kementerian Luar Negeri Republik Indonesia, 15 November. [online] https://www.kemlu.go.id/id/berita/siaran-pers/Pages/Presiden-Jokowi-Deklarasikan-Indonesia-Sebagai-Poros-Maritim-Dunia.aspx [accessed at 13 January 2019].

Kementerian Luar Negeri Republik Indonesia, 2017. "RI Ingin Perkuat Poros Maritim melalui Kerjasama Bisnis IORA [Republic of Indonesia wants to strengthen Maritime Fulcrum through IORA business cooperation]" Kementerian Luar Negeri Republik Indonesia, 6 March 2017. [online] https://www.kemlu.go.id/id/berita/ siaran-pers/Pages/RI-Ingin-Perkuat-Poros-Maritim-melalui-Kerja-Sama-BisnisIORA.aspx [accessed at 5 January 2019].

Kementerian Luar Negeri Republik Indonesia, 2017. "Sentralitas ASEAN Sebagai Perekat Perdamaian dan Keamanan di Kawasan [ASEAN Centrality as the adhesive for regional peace and security]". Kementerian Luar Negeri Republik Indonesia, 20 May. [online] https://www.kemlu.go.id/id/berita/Pages/Sentralitas-ASEAN-Sebagai-Perekat-Perdamaian-dan-Keamanan-di-Kawasan.aspx [accessed at 5 January 2019].

Kementerian Luar Negeri Republik Indonesia, 2019. "Kerja Sama Eksternal ASEAN Mitra Wicara Organisasi Internasional ASEAN [ASEAN external cooperation, talking partner with international organization ASEAN]." Kementerian Luar Negeri Republik Indonesia, 2 Januari. [online] https://www.kemlu.go.id/id/kebijakan/asean/Pages/Kerja-Sama-Eksternal-ASEAN-Mitra-Wicara-Organisasi-Internasional-ASEAN.aspx [accessed at 5 January 2019]. 
Kelen, Yos. 2014. "Tujuh Alasan Indonesia Masih Sulit Menjadi Poros Maritim Dunia [Seven Reasons Why It is difficult for Indonesia to become Global Maritime Fulcrum]", Suara Pembaharuan, 16 August. [online] https://sp.beritasatu.com/ home/tujuh-alasan-indonesia-masih-sulit-menjadi-poros-maritim-dunia/62155 [accessed at 13 Januari 2019]

Fabian Januarius Kuwado, 2017. "Susi Pudjiastuti: Indonesia Poros Maritim Dunia Hanya Slogan? [Susi Pudjiastuti: Indonesia's Global Maritime Fulcrum is only a slogan?]", Kompas, 30 October. [online] https://nasional.kompas.com/ $\mathrm{read} / 2017 / 10 / 30 / 09370631 /$ susi-pudjiastuti-indonesia-poros-maritim-dunia-hanya-slogan-doang [accessed at 5 January 2019]

Laksmana, Evan A. 2010. "Challenges for Indonesia's Foreign Policy in Transition," Today Newspaper, 27 February. [online] https://www.academia.edu/37049276/ Challenges_for_Indonesia_s_foreign_policy_in_transition. [accessed at 14 January 2019]

Laksmana, Evan A. 2018a. "Buck Passing from behind, Indonesia's Foreign Policy and the Indo-Pasific", Brookings, 27 November. [online] https://www.brookings.edu/ blog/order-from-chaos/2018/11/27/buck-passing-from-behind-indonesias-foreign-policy-and-the-indo-pacific/ [accessed at 29 November 2018].

Laksmana, Evan A. 2018b. "Indonesia's Indo Pacific Vision Call Asean Stick Together”, South China Morning Post, 20 November. [online] https://www.scmp.com/ week-asia/geopolitics/article/2173934/indonesias-indo-pacific-vision-call-asean-stick-together. [accessed at 21 November 2018]

Lee Hsien Loong, 2018. "PM Lee Hsien Loong at Opening Ceremony of $50^{\text {th }}$ ASEAN Economic Ministers Meeting," ASEAN Economic Ministers Meeting, 29 August. [online] https://www.pmo.gov.sg/Newsroom/pm-lee-hsien-loong-opening-ceremony-50th-asean-economic-ministers-meeting. [accessed at 30 August 2018]

Investor Daily. "2018, Indonesia Fokus Perkuat Persatuan dan Sentralitas Asean [2018, Indonesia focuses on strengthening the unity and the centrality of Asean]", 10 January. [online] https://id.beritasatu.com/home/2018-indonesia-fokus-perkuat-persatuan-dan-sentralitas-asean/170522. [accessed at 11 January 2019]

Minghao, Zhao 2018. "Five Years On, BRI Tastes Success on Several Fronts", Global Times, August 28. [online] http://www.globaltimes.cn/content/111740o.shtml [accessed at 30 August 2018]

Poole, Avery, 2015. "Is Jokowi turning his back on ASEAN?", Indonesia at Melbourne, September 1. [online] http://indonesiaatmelbourne.unimelb.edu.au/is-jokowiturning-his-back-on-asean/[accessed at 2 September 2018]

Sheany, 2018. "Indonesia to Boost Efforts in Economic Diplomacy", The Jakarta Globe, 12 February. [online] http://jakartaglobe.id/news/indonesia-boost-efforts-economic-diplomacy/ [accessed at 13 February 2018]

Sinintya, Wangi. 2018. "AS-China Perang Dagang, Asia Tenggara Pemenangnya", CNBCIndonesia, 23 November. [online] https://www.cnbcindonesia.com/ news/20181123162917-4-43440/as-china-perang-dagang-asia-tenggara-pemenangnya [accessed at 24 November 2018]

Tsvetov, Anton. 2017. "Will the Quad Mean the End of ASEAN Centrality?" The Diplomat, 11 November. [online] https://thediplomat.com/2017/11/will-the-quad- 
mean-the-end-of-asean-centrality/ [accessed at 13 November 2018]

Van Sant, Shannon. 2016. "China Slowdown Impacts Neighbors, But Other Factors Offer a Buffer”, Voice of America, June 27. [online] https://www.voanews.com/a/ china-slowdown-impacts-neighbors-but-other-factors-offer-a-buffer/3393447. html [accessed at 30 June 2018].

Sihombing, Anthon. 2017. "IORA dan Kabar Indonesia sebagai Poros Maritim Dunia [IORA and the news of Indonesia as Global Maritime Fulcrum]", Kompas.com, 23 March 2017. [online] https://ekonomi.kompas.com/read/2017/o3/23/211319426/ iora.dan.kabar. indonesia.sebagai.poros.maritim.dunia [accessed at 26 Maret 2018]

Wadrianto, Glori K. 2016. "Menlu RI: Sentralitas dan Kesatuan adalah Kunci bagi ASEAN”, Kompas.com, 25 Juli. [online] https://internasional.kompas.com/ $\mathrm{read} / 2016 / 07 / 25 / \quad$ 06570421/menlu.ri.sentralitas.dan.kesatuan.adalah.kunci. bagi.asean. [accessed at 28 July 2018]

Witular, Rendi A. 2014. "Jokowi launches maritime doctrine to the world”, The Jakarta Post, 13 November. [online] https://www.thejakartapost.com/news/2014/11/13/ jokowi-launches-maritime-doctrine-world.html. [accessed at 13 January 2019].

Whyte, Alexander. 2012. "Neorealism and Neoliberal Institusionalism Born of The Same Approach", E-International Relations Students, June 11, [online] https://www.e-ir.info/2012/o6/11/neorealism-and-neoliberal-institutionalism-born-of-the-same-approach/ [accessed at 13 January 2019]

\section{Others}

Marsudi, Retno. 2018. "Pernyataan Pers Tahunan Menteri Luar Negeri Republik Indonesia Y.M. Retno L. P. Marsudi Tahun 9 Januari 2018 [Annual Pers Conference of Her Excellency Foreign Minister of Republic of Indonesia Retno L.P. Marsudi on 9 January 2018”, Kementerian Luar Negeri Republik Indonesia, 9 January 2018.

Natalegawa, Marty. 2013. “An Indonesian Perspective on the Indo-Pacific.” In Keynote Address by HE Dr. RM Marty M. Natalegawa, Foreign Minister, Republic of Indonesia, at the Conference on Indonesia, Washington, DC, vol. 16.

Sebastian, Leonard C. 2014. "Indonesia's Dynamic Equilibrium and ASEAN Centrality", In The National Institute for Defense Studies, The NIDS International Symposium on Security Affairs 2013 